USBAD Uluslararası Sosyal Bilimler Akademi Dergisi -

International Journal of Social Sciences Academy, Yıl 2, Year

2, Sayı 4, Issue 4, Aralık 2020, December 2020.

e ISSn: 2687-2641

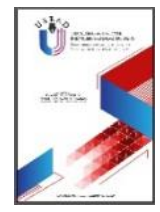

\title{
DIŞ POLİTiKANIN SOSYAL İNŞASI: KÜLTÜREL FAKTÖRLERİN KARAR ALMA YAPILARINA ARTAN ETKİSİ
}

THE SOCIAL CONSTRUCTION OF FOREIGN POLICY: THE INCREASING IMPACT OF CULTURAL FACTORS ON DECISION-MAKING STRUCTURES

\section{Can DONDURAN}

Araştırma Görevlisi, Uluslararası İlişkiler, İstinye Üniversitesi, İstanbul/Türkiye.

Research Assistant, International Relations, İstinye University, Istanbul/Turkey.

can.donduran@istinye.edu.tr

ORCID ID: 0000-0003-2737-1410

Makale bilgisi | Article Information

Doİ: $10.47994 /$ usbad.818011

Makale Türü / Article Type: Araştırma Makalesi / Research Article

Geliş Tarihi / Date Received: 29.10.2020

Kabul Tarihi / Date Accepted: 17.12.2020

Yayın Tarihi / Date Published: 20.12.2020

Yayın Sezonu / Pub Date Season: Aralık / December

Bu Makaleye Atıf İçin / To Cite This Article: Donduran, C. (2020). Dış Politikanın Sosyal İnşası: Kültürel Faktörlerin Karar Alma Yapılarına Artan Etkisi. USBAD Uluslararası Sosyal Bilimler Akademi Dergisi 2(4), 1054-1083.

İntihal: Bu makale intihal.net yazılımınca taranmıştır. İntihal tespit edilmemiştir.

Plagiarism: This article has been scanned by intihal.net. No plagiarism detected.

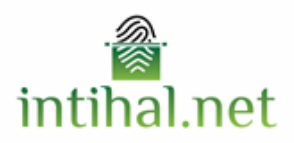

İletişim: Web: https://dergipark.org.tr/tr/pub/usbad mail: usbaddergi@gmail.com 
Öz: Bu çalışmada, kültürel faktörlerin ve kimliklerin dış politika alanında devletlerin karar alma mekanizmaları üzerindeki artan etkisi incelenecektir. Öncelikle, bağlamsal bir analizle, kültür ve dış politika kavramlarının kesiştiği noktanın evrimi tarihsel bir perspektiften ele alınacak olup; sonrasında, Soğuk Savaş sonrası dönemde uluslararası politikanın değişen doğası ve İnşacı Uluslararası İlişkiler teorisinin dış politikanın kültürel bir analizini mümkün kılan katkıları, bu çalışmanın odak noktasını oluşturacaktır. Disiplindeki hâkim ana akım görüşün aksine, uluslararası aktörlerin kendilerine özgü özellikleri, uluslararası seviyedeki davranışlarını şekillendirmede veya karar alıcıya uygun dış politika alternatiflerinin belirlenmesinde gittikçe etkili hale gelmektedir. Bireyleri analizin merkezine yerleştirmek ve onların etkileyen sosyal süreçleri hesaba katmak, zaman içerisinde çok daha kapsamlı ve isabetli sonuçlara ulaşımasını sağlayacaktır. Bu yaklaşım, aynı zamanda, kültürel faktörlerin ve kimlik yapılarının dış politika analizine dahil edilmesine önemli katkıda bulunacaktır. Kültür ve dış politika arasındaki ilişkinin değişen konjonktürdeki değişiminin incelenmesi de kültürel faktörlerin nasıl ve ne ölçüde dış politika çıktıları ve karar alma mekanizmaları üzerinde etkili olduğunu ortaya çıkaracaktır.

Anahtar Kelimeler: İnşacılık, Kültür, Kimlik, Dış Politika

Abstract: In this study, the growing impact of cultural factors and identities on the decision-making mechanisms of international actors within the realm of foreign policy will be examined. Through a contextual analysis, we will first develop, from a historical perspective, a comprehensive understanding of the evolution of the culture-foreign policy nexus. Then, the changing nature of international politics in the post-Cold War era and the contributions of Constructivist IR theory with regard to a cultural analysis of foreign policy will constitute the focal point of this work. Contrary to the mainstream view prevailing within the IR discipline, the idiosyncrasies of the international actors have incrementally become influential in shaping their behaviors abroad or in limiting the foreign policy options available to decision-makers. Placing individuals at the heart of the analysis and taking the impact of the social processes they have been through will eventually lead to more comprehensive and accurate conclusions. Such an approach will also be helpful in integrating the cultural factors and the identity structures into foreign policy analysis. The analysis of the transforming relations between culture and foreign policy will, in the end, reveal how these factors come to affect foreign policy outputs and the decision-making processes and the extent to which they have become influential.

Keywords: Constructivism, Culture, Identity, Foreign Policy 


\section{GİRIŞ}

Kültürel faktörlerin ve kimlikle ilişkili yapıların devletlerin dış politika alanındaki karar ve davranışlarına etkisi uzun zamandır tartışılan bir konu olarak akademik çevreleri meşgul etmiştir. Geleneksel raison d'état kavramına bağı analizler, davranışsalcılığın alandaki hakimiyetiyle dış politika analizi noktasında etkin konumda değerlendirilmese de özellikle Soğuk Savaşıın son dönemlerinden bugüne, analizin merkezine insanı yerleştiren yaklaşımların hızla güç kazanmasıyla birlikte bu konuya ilişkin çalışmalar noktasında her açıdan bir artış göze çarpmaktadır.

Kültür kavramı ve bu kavramla ilişkili olan kimlik üzerine odaklanan uluslararası ilişkiler çerçevesindeki analizler son yıllarda nicelik olarak hızla artarken bu kapsamdaki çalışmalar adına şekillenen perspektifler noktasında da kayda değer bir çeşitlenme görülmektedir. Bu gidişat, her ne kadar özellikle bu alanla yeni ilgilenenler açısından yanıltıcı olabilse de aslında olan, kültür ve kimliğin bu alanda keşfedilmesi değil, klasik yaklaşımlardan farklı biçimlerde, ortaya çıkan yeni dönüşümlerle uyumlu olarak bu kavramların yeniden ele alınmasıdır. Başka bir ifadeyle, "kültür gemisi" kıyıda, henüz keşfedilmemiş birçok hazineyi keşfetmek için geri dönmektedir (Lapid, 1996: 6).

Kültürel faktörlerin ve kimlik yapılarının dış politika yapımını önemli ölçüde etkileyen değişkenler olduğunu gösteren dönüşümlerin özellikle 1990'lı yıllardan itibaren giderek artması, birçok farklı etmene bağlı olarak şekillenmektedir. Bunların içerisinde öncelikle, uluslararası sistemin değişen doğası, devlet-dışı aktörlerin artan etkinliği ve uluslararası aktörler arasında gittikçe yoğunlaşan etkileşim yatmaktadır. Bunların yanında, Uluslararası İlişkiler disiplini içerisinde, teorik düzlemde yaşanan aydınlanma da bu yöndeki görüşleri güçlendirmiştir. Analizin merkezine egemen birimleri konumlandırma yönündeki eğilimin azalan baskınlığı ve bireye atfedilen önemin artması, bu yöndeki gelişmelerin hızlanmasında önemli rol oynamıştır. İnşacı uluslararası ilişkiler teorisi tam da bu noktada dış politika analizine dair en büyük katkısını sunmuş ve kültür kavramının analitik çerçeveye tekrar, daha güçlü bir biçimde eklemlenmesini sağlamıştır.

Belirtilen çerçeve içerisinde, bu çalışmada, bağlamsal analiz yöntemi ile kültür ve dış politika ilişkisinin son dönemlerdeki evrimi ele alınacak ve uluslararası aktörlerin dış politika davranışlarının 
analizinde, bugün gelinen noktada, söz konusu yapıların artan önemi incelenecektir. Bu bağlamda, ilk bölümde, tarihsel bir perspektiften kültürel faktörlerin dış politikaya etkisine bakışın değişimine değinilecek ve daha sonra hem teorik anlamda hem dış politika analizi çerçevesinde son yıllarda ortaya çıkmaya başlayan değişim incelenecektir. Sonraki bölümde ise kültürel faktörlerin devletlerin çevrelerine yönelik algılarının şekillenmesindeki rolü ve bunun dış politika yapımına ve davranışına etkisi öncelikli olarak ele alınacak olup devamında, dış politikanın yapımına odaklanmak suretiyle, bu yapıların karar alma üzerindeki etkileri analiz edilecektir. Bu şekilde, kültür ve kimlik ile ilişkili faktörlerin devletlerarası ilişkiler açısından önemi açıklanmaya çalışılacaktır. Bu çalışma ile temel olarak, söz konusu faktörlerin hem Uluslararası İlişkiler disiplini hem de dış politikada karar alma analizi açısından değeri vurgulanırken, bu yapıların ele alınış biçimlerinin, bu çerçevede gerçekleştirilen bir analizin güçlülüğü için ne kadar önemli olduğu gösterilmeye çalışılacaktır.

\section{KÜLTÜR VE DIŞ POLİTIKA İLIŞKİSİNİN EVRİMí}

Dış politika yapımına ve bu süreci etkileyen faktörlere dair hangi görüşün savunulduğuna bakılmaksızın hemen herkesçe kabul edilen gerçek, söz konusu sürecin bir boşlukta gerçekleşmediği ve aktörün içerisinde bulunduğu uluslararası bağlamın, bu noktada önemli bir belirleyici olduğudur. Bu sistemik bağlam, aynı zamanda, analizin gelişip zenginleşmesi adına da kritik önemdedir. Kültürel yapılar ve kimlik algılarının dış politika davranışlarına etkisinin tekrar keşfedilmesi açısından da uluslararası sistemdeki köklü değişimler önemli rol oynamıştır. Soğuk Savaş'ın ideolojik mücadele ile şekillenen keskin atmosferi, devletlerarası ilişkilerin analizinde kimlik ve kültürün geri planda kalmasının temel sebebidir. Blokların içerisinde, ideolojik birlik üzerinden üretilmeye çalışılan homojenlik algısı, devletlerin farklılıklarının maskelenmesine yol açmış ve bu yöndeki çabalar, kültürel farklılıkların önemsizmiş gibi yorumlanmasına sebep olmuştur. Farklı bir biçimde ifade edilirse, "iki kutupluluk, ulusların kendine özgü olan niteliklerini gölgede bırakmıştır" (Hudson, 2014: 141). Temelde kültür ve kimliğin sorunsallaştırımaması, süper güçler arasındaki hiç bitmeyecekmiş gibi görünen bir mücadelenin dayattığı önceliklerin koşulsuz kabul edilmesinin bir sonucudur. Bu keskin atmosferde yaşanan, özellikle sömürgeciliğin sona ermesiyle ilişkili gelişmeler, hızlanan küreselleşmenin marjinalleştirdiği kitlelerin son umudu olan sosyalizmin gittikçe zayıflaması ve bunu izleyen süreçte Sovyetler 
Birliği'nin dağılmasıyla ideolojik rekabetin sona ermesi, kültürel farklııklara ve kimliksel aidiyetlere yapılan vurguyu artırmıştır (Heywood, 2011: 181-187). Buna paralel olarak, Uluslararası İlişkiler disiplini içerisindeki Üçüncü Büyük Tartışma ile iyice açığa çıkan, önceden verili gerçeklere dayanarak klasik perspektifte geliştirilen analizlerin radikal dönüşümleri, Rosenau'nun (1990) sözleriyle ifade edilirse, "türbülansları" anlama ve yorumlamadaki yetersizliği de kültürel faktörlerin bu çerçevede önem kazanmasında ciddi rol oynamıştır. Buna göre, analiz artık problem çözmeye odaklanmaktan çıkarak farklı aktörlerin de uluslararası olgu ve olaylarda merkezi konumda kabul edildiği bir bakışa yönelmelidir. Bu yaklaşım hem teorik hem de yöntemsel anlamda oldukça büyük bir değişim yaratmıştır.

Teorik çerçevede en temel kırılma noktasını, İnşacı (Konstrüktivist) bakış açısının gelişmesiyle birlikte hızla güç kazanan; kültür, kimlik gibi kavramların doğal olarak verili kabulüne karşı çıkarak, bunları sosyal manada inşa edilmiş yapılar olarak ele alma fikridir (Wendt, 1992, 1995; Lapid, 1996). Devletlerin dış politika davranışlarının belirlenmesinde ulusal çıkarların önemi ve önceliği hususunda klasik yaklaşımlarla fikir birliği içerisinde olan bu bakış açısına göre, sosyal süreçler aracılığıyla inşa edilen kültür ve buna bağlı olarak anlam kazanan kimlik, çıkarların belirlenmesinde, dolayısıyla, devletlerin davranışlarının ve tercihlerinin şekillenmesinde belirleyici rol oynar (Hopf, 1998; Price ve Reus-Smit, 1998). Epistemolojik ve ontolojik açıdan değerlendirildiğinde, klasik teoriler ile görece uyumlu olarak değerlendirilebilecek bu yaklaşım, sunduğu yorumlamacı bakış açısıyla, disiplin içerisinde gerçekleştirilen analizlere önemli bir katkıda bulunmuştur. Öznelerarası anlayışa yaptığı vurgu ile geleneksel vizyonun deterministik yaklaşımına meydan okuyan inşacılık, bu alandaki çalışmaların özellikle 1990'ı yıllardan itibaren gösterdiği gelişimde önemli rol oynamıştır. Bu noktada altı çizilmelidir ki bütün bu söylenenler, İnşacı bakış açısıyla gerçekleştirilen analizlerin her olayı tam anlamıyla aydınlatacağı ya da bugüne kadar disiplin içerisinde karanlıkta kalmış bütün noktalara ışık tutacağı gibi bir iddiada bulunmaktan uzaktır. Belirtilmek istenen yalnızca, kültür ve kimliğin inşa edilen, çok boyutlu yapılar olarak ele alınmasının ve devletlerin davranışlarını şekillendiren ulusal çıkarları ile bu yapılar arasındaki karşılıklı ilişkinin vurgulanmasının, bu konular üzerine yoğunlaşan çalışmaların zenginleşmesi ve ufkunun genişlemesi adına oldukça faydalı olduğudur. 
Buraya kadar bahsedilen değişim, Uluslararası İlişkiler disiplinin genelinde olduğu gibi, 20. yüzyılın ortalarından beri gelişmekte olan dış politika analizi ve karar alma odaklı çalışmalardaki gelişimi kaçınılmaz olarak hızlandırmış ve yine disiplinin genelinde olduğu gibi, bu alandaki çalışmalar üzerinde de vizyon genişletici bir etkide bulunmuştur. Dış politika analizi çerçevesinde bakıldığında da kültür kavramının iki kutuplu düzenin son dönemlerine ait bir keşif olmadığını söylemek mümkündür. Jean-Frédéric Morin'in (2013: 97) de vurguladığı gibi "aslında dış politika analizi kültürle ilgilenmeyi asla kesmemiştir (...) [Dış politika analizi çalışmalarının] epistemolojik anlamda klasik duruşu, kültürü dış politikaya nedensel ilişkilerle bağlı bir bağımsız değişken olarak ele almaktır." Bu bağlamda, 1960'lı yıllarda geçekleştirilen çalışmalar (Pye ve Verba, 1965; Almond ve Verba, 1963), dış politika analizi odaklı incelemelerde kültür kavramına klasik bakışı en net biçimde yansıtmaktadırlar. "Toplumun siyasi sistemle bağlantı kuran değer ve inanışlarının bir altkümesi" (Almond ve Verba, 1989) olarak tanımlanan siyasi kültür, klasik dönemde de analizin önemli noktalarından birisini oluşturmuştur. İlerleyen dönemlerdeki gelişmelere paralel olarak, bu alanda da oldukça farklı biçimde ele alınan kültür kavramı ve görünürlüğü gittikçe artan kimlik vurgusu, dış politika analizi çalışmalarında kayda değer bir dönüşüm sergilese de alanın klasik eserlerindeki kültüre bakış açısı, önemli bir yola çıkış noktası olarak akıldan çıkarılmamalıdır.

Dış politika analizindeki klasik çalışmalarda genel olarak kültür, teorinin açıklayamadığı her şeyin sorumluluğunun üzerine atıldığı bir "son çare açıklaması" olarak değerlendirilmekteydi (Pye, 1991; Hudson, 2014: 121). Bu bakış açısı, Rosenau'nun (1980: 370-401) daha sonra gözden geçirdiği "bağıntı kuramı" çerçevesinde ele alınan, rejim, ekonomik faktörler ve ulusun heterojen yapısı ile ilişkilendirilen "toplumsal değişken" (societal variable) çerçevesinde incelenerek biraz olsun geleneksel sınırlamalarından kurtulmuş olsa da çalışmalardaki konumu, yine daha önemli görülen başka faktörlerle kısıtlanmıştır. Hudson'a (2014: 120-121) göre, kültür kavramının geleneksel çalışmalar çerçevesindeki tanımları bu yetersizliğin oluşmasında önemli rol oynarken, kültürel çalışmaların yeniden doğuşu bu tanımların yeniden gözden geçirilmesiyle mümkün olmuştur. Frode Liland'ın (1993: 5-34) da çalışmasında vurguladığı gibi, dış politika ile kültür arasındaki ilişkinin soyut ya da somut olması, önemli ya da sınırlı önemde görülmesi noktasında farklılaşan fikirlerin mevcut olmasıyla 
birlikte kültür, bütün dış politika kurumunun içerisindeki çevreyi oluşturması dolayısıyla dış politikanın temeli, ayrılmaz bir parçası ve hatta kaynağı olarak ele alınmalıdır. Disiplin içerisindeki kökenlerinden tam bir kopuş içermemek kaydıyla, kültürün dış politika analizi çerçevesinde daha dinamik bir yapı olarak ele alınır hale gelmesi, 1990 'lı yıllarda ortaya çıkan uluslararası siyaset alanına ilişkin radikal dönüşümlerin kaçınılmaz bir sonucu olarak değerlendirilmektedir (Gaenslen, 1997: 265-270).

Bunlarla birlikte, kültürel faktörlerin dış politika analizi ile ilişkisinin önemini vurgulayan temel bağlantı noktaları da oldukça çeşitlidir. Dış politika ve karar alma analizi alanında kültürel faktörlerin ve kimlik yapılarına ilişkin aidiyetlerin önem kazanması, temelde iki ana noktayla ilişkilidir. Bunlardan ilki, aktörlerin içeride ve dışarıda olan biteni algılaması adına bu faktörlerin belirleyici bir rolü olduğunun kabulüne dayanır. Devletlerin dış politika ve uluslararası alanı algılamaları, büyük ölçüde kimliklerinin özelliklerine bağlıdır (Baklacıoğlu, 2014: 64). Bu bağlamda, dış politika davranışlarının da bu algılamalar doğrultusunda yorumlanan çıkar anlayışı üzerinden şekillenecek olması, bu yapıların devlet eylemlerinin anlaşılması, yorumlanması ve ön görülmesi açısından önemini göstermektedir. Ayrıca, devletin kendine dair sahip olduğu kimlik algısının dışında diğer aktörlere atfettiği kimlikler de dış politika davranışıyla yakından ilişkilidir. Bu durum, içinde bulunduğu bağlamda, ilişki kurduğu devletlerin kimliklerine göre aynı devletin farklı şartlarda farklı bir aktör gibi yorumlanmasına yol açabilir. Yakın tarihte, bu durumun en açık örneklerinden birisini, Irak-Kuveyt Savaşı sırasında Irak'ın Suudi Arabistan'a yaklaşımı oluşturmaktadır. Saddam Hüseyin yönetimindeki Irak'ın Suudi Krallığı'nı "egemen bir devlet" yerine "kafirlerle" iş birliğini kategorik olarak reddedecek "Arap/Müslüman" kimlikli bir devlet olarak algılaması, savaşın gidişatını önemli biçimde etkileyecek kararların alınmasında önemli rol oynamış ve belki de bu noktadaki yanılgı, Irak için savaşın kaderinin olumsuz yönde çizilmesine yol açmıştır (Barnett, 1993: 277). Kısacası, devletlerin uluslararası düzlemde ortaya çıkan olayları, olguları, sorunları algılayıp yorumlaması ve bu durumlara karşı tercihlerini şekillendirmesi noktasında kültür ve kimlikle ilişkili yargılar önemlidir. Bu da bizi dış politika ve karar alma üzerine gerçekleştirilen çalışmalar için kültürel faktörler ve kimliğin önemini gösteren ikinci noktaya getirmektedir. 
Bu anlamda vurgulanmak istenen, söz konusu bu eylemlerin doğrudan devlet olarak adlandırılan yapı tarafından değil, onun işleyişini biçimlendiren insan tarafından yapılıyor olduğudur. Bir başka deyişle, analizin karar alma kısmına odaklanıldığında karşımıza çıkan insan faktörü, kültürel etmenleri ve kimliksel aidiyetleri, göz ardı edilemez derecede etkili yapılar olarak karşımıza çıkarmaktadır. Bir başka ifadeyle, analizin merkezine bireyin yerleştirilmesi, kaçınılmaz bir gereklilik olduğu kadar geleneksel olarak kabul edilegelmiş birçok hususta da değişim yaşanması sonucunu doğurmuştur. Bu değişimin varsayımını net bir biçimde ifade etmek gerekirse, "devletler aktör değildir çünkü devlet bir soyutlamadır. (...) Bireylerin aktörlüğü, bütün uluslararası politikaların ve bu alandaki değişimlerin kaynağıdır" (Hudson, 2005: 2-3). Bu anlamda, bir kurgu olarak değerlendirilmesi gereken devletin davranışları, bu kurgunun işletilmesini sağlayan, karar alma noktasında etkin role sahip birey ya da bireylerin düşünsel yapılarından ayrı değerlendirilemez. Bireylerin bu anlamdaki kapasite ve eğilimlerinin biçimlenmesi üzerinde kültür ve kimlik aidiyetlerinin belirleyici etkisi düşünüldüğünde, bu yapıların dış politika analizi çerçevesinde karar alma noktasında ne kadar önemli olduğu açıkça görülebilir. Hermann ve Kegley Jr.'ın (1995: 514) da vurguladığı gibi, bu alandaki "kapsamlı bir açıklama, karar vericiyi dışsal olarak ele almakla mümkün olamaz." Yani, analizin odağının birey faktörüne yoğunlaşması, kaçınılmaz olarak bireyin hayata ve olaylara bakışını şekillendiren, içinde yetiştiği, aidiyet hissettiği/hissetmediği değer ve inançların, söz konusu bireyin hareketlerinin sınırlarını çizen kural ve normların dikkatle incelenmesini gerektirmektedir.

Bunun yanında, dış politika kararlarının alınması noktasında tercih edilen yöntemin, bu yöntem içinde farklı roller oynayan bürokratik yapıların ve karar alma sürecinin doğasının belirlenmesi noktasında da kültürel değişkenlerin etkisinden söz edilebilir. Sampson (1987: 384405), bu çerçevede, Fransa ve Japonya'nın kültürel özelliklerinden yola çıkarak karar alma yapılarının ve dış politika yönelimlerinin ne şekilde biçimlendiği ve bunda kültürel faktörlerin rolünü çok net bir biçimde gözler önüne sermiştir. Bu anlamda, özellikle devletin rejimi, bürokratik karar alma yapılarının kendi iç işleyişi ve bireylerin bu kurumlardaki konumlarına paralel olarak geliştirdikleri kimlik algısı çok önemli hale gelmektedir. 


\section{DEVLETLERİN ÇEVRE ALGILARI VE KARAR ALMA SÜREÇLERİ ÜZERİNDE KÜLTÜRÜN ETKİSİ}

Sosyal süreçler sonucunda inşa edilmiş kültürel özelliklerin ve kimlik aidiyetlerinin dış politikaya etkisi iki farklı yönden gerçekleşmektedir. Bunlardan ilki, bahsedilen faktörlerin dış dünyanın ve burada meydana gelen gelişmelerin ele alınan aktörce algılanıp yorumlanması ile ilişkilidir. Bu noktada, aktörün kendisine ilişkin algısı da dolaylı olarak da olsa rol oynamaktadır. Bir devletin uluslararası sistemde kendisini konumlandırdığı yer, onun, çevresindeki sorunları yorumlaması ve bu sorunlara karşı takınacağı tutumunu şekillendirmesi açısından belirleyici özelliktedir. Uluslararası barış ve istikrarın koruyucusu kimliğini kendisine atfetmiş olan bir devlet, dünyanın herhangi bir noktasında yaşanan çatışmayı çözme sorumluluğunu kendi üzerinde hissedebilir ve bu doğrultuda harekete geçme gereksinimini hissedebilir. Aynı şekilde bu devlet, tepkisiz kaldığı bu tarz durumlarda hem içeriden hem de dışarıdan eleştirilerin hedef noktasında kendisini bulabilir. Ancak, bu ya da buna benzer bir kimliğe sahip olma inanışında olmayan bir devlet için böyle bir çatışma, kendi çıkarlarını doğrudan etkilemediği müddetçe görmezden gelinebilir bir hadise olarak kalacaktır.

Sayfa | 1062

İkinci nokta ise daha çok aktörlerin karar alma mekanizmasının yapısı ve işleyişi ile alakalıdır. Bu mekanizma çerçevesinde nüfuzlu noktalarda bulunanların bireyler olması, bu süreçte de bireylerin görüş ve yaklaşımlarının içerisinde şekillendiği kültürün ve sahip oldukları bireysel kimlik aidiyetlerinin bu anlamda belirleyici olmasına yol açar. Bireylerin zihinleri bir boşlukta bulunup çevrede yaşanan gelişmelere bağımsız tepkiler veren yapılar değildir. Çocukluklarından itibaren çeşitli sosyal koşullandırılmaların bir ürünü olarak yetişip bulundukları noktaya ulaşan karar verici bireyler, her olay karşısındaki eğilimleri ve karar alternatiflerinin belirlenmesi açısından bu koşullandırmaların izlerini barındırırlar. Devlet, canlı bir organizma değildir ve bireylerden bağımsız olarak düşünemez, karar alamaz. Dolayısıyla devletin dış politika alanındaki rasyonelliği ve objektifliği, bu konuda karar alan bireylerinkiyle sınırlıdır. Buna göre devlet, kendisini meydana getiren bireylerin kültürel değer ve inanışlarından etkilenmek suretiyle hareket edebilir. Bu anlamda kültürel faktörler ve kimlik, yalnızca devletin davranışlarını etkileyen unsurlar değil aynı zamanda onun yapısını şekillendiren etmenler olarak da karşımıza çıkar. 


\section{AKTÖRLERİN \\ ÇEVRELERİNí \\ ALGILAMASI \\ VE YORUMLAMASI}

Marcel Proust (2010: 100), Kayıp Zamanın İzinde adlı eserinde; "ulusların yaşamı, onları oluşturan küçük hücrelerin yaşamlarını daha büyük ölçekte tekrar etmekten fazlasını yapmaz ve bu küçük yaşamların gizemini, tepkilerini, kanunlarını anlayamayan birisi uluslar arasındaki mücadele ile ilgili sadece beyhude beyanlarda bulunur" diyerek mikro ölçekte şekillendirici etkisi büyük olan kültürün anlaşımasının, devletler arasındaki ilişkiler bağlamındaki önemini net biçimde açıklamıştır. Toplumun ve dolayısıyla bireylerin yaşayış ve dış dünyayı algılayış biçimlerine yön veren, paylaşılan normlar, değerler, inanışlar, semboller, devletin durumları yorumlaması ve bu durumlara karşı bir davranış geliştirmesi noktasında inmal edilemez derecede önemlidir. "Gerçekten de dünyayı anlamak ve yorumlamak sadece muayyen bir kültürel ve dilsel çerçeve içerisinden mümkündür; bu çerçeveler dünyayı algıladığımız merceklerdir" (Burchill ve Linklater, 2013: 34).

Uluslararası politika alanında, özellikle Soğuk Savaş sonrası dönemde, kültürel faktörlerin potansiyel çatışmalarda önemli rol oynama potansiyeline sahip olduğu fikri birçok analizin içerisinde önemli yer tutmuştur. Bunların en çok ses getireni hiç şüphesiz, aslında mevcut ve gelecekteki çatışmaların hepsinin kültürel kökenlere dayandığı iddiasında bulunan, Samuel Hunington'a (1996) ait Medeniyetler Çatışması başlıklı çalışmadır. İzleyen süreçte, 2001 yılında gerçekleşen 11 Eylül saldırıları, kültürün ele alınışı noktasında ve kültürel etmenlerin öneminin genel olarak kabul görmesine yol açması anlamında önemli bir kırılma oluşturmuştur.

Kültürün tanımı, yorumlanması ve analiz içerisinde ele alınış biçimindeki değişiklik ise uluslararası olgularla ilişkili olarak öneminin artmasını sağlamıştır. Hudson'ın (2014: 120-121) kitabının ilgili bölümünde beş farklı başlık altında incelediği geleneksel kültür tanımları bu konudaki dönüşümü net bir biçimde göstermektedir. Bu çalışmanın ölçeği gereği, bu başlıklardan her birini detaylı olarak analiz etmek mümkün olmasa da genel anlamda kültürü monolitik ve dinamik olmaktan uzak bir yapı olarak değerlendiren bu yaklaşımlar, yapılar arasındaki etkileşimin gücünü inmal ederek (ya da oldukça sınırlı görerek) etkinliğinin az olduğu sonucuna varmaktadır. Bu anlamda, kültürün sadece sonuç merkezli dış politika analizlerine neredeyse hapsolması ve bir "son çare açıklaması" olarak görülmesi kaçınılmaz 
hale gelmektedir. Kültürün etkisini iddia eden hipotezlerin klasik teorik mantıkla yanlışlanması da oldukça zor olduğundan, kültürel faktörler, çalışmalarda geri plana itilmiştir.

Kültürel çalışmaların "yeniden doğuşu" işte tam bu noktadaki dönüşüme işaret etmektedir. Kültürün, bir iletişimi etkileyen inşa edilmiş bir anlamlar bütünü, tercih edilen değerler noktasında ortaklık oluşturarak bazı tahmin edilebilir davranışlara yönlendiren bir yapı ve bireyin izleyeceği stratejinin kalıbını şekillendiren bir etmen olarak ele alınması (Hudson, 2014: 122-125), yapılar arasındaki karşılıklı etkileşimlerin biçimlendirici etkisinin de vurgulanmasıyla birlikte bu göz ardı edilemez dönüşümü ortaya çıkarmıştır. Söz konusu yeni dönem çalışmalarda "(...) karar alıcıya sunulan seçeneklerin çeşitliliğini sınırlayan veya farklı seçeneklerin görünümünü ya da etkinliğini değiştiren" (Johnston, 1995: 42) bir yapı olarak tanımlanan kültür, bu haliyle, dış politika yapımının temel etmenlerinden biri olarak ele alınmaya başlamıştır. Bunun yanında, alanda düşünsel boyuta artan ilgi sonucu kültürün fikirler ve inanışlar üzerindeki göz ardı edilemez etkisinin kabulü, kültürel faktörlerin bu konuya ilişkin analizlerdeki önemli rolünü perçinler nitelikte etkide bulunmuştur. Goldstein ve Keohane'in (1993: 3) de vurguladığı gibi; fikirler, siyasi kurumlarda vücuda gelen nedensel ve temel inanışları bütünleştirerek, aktörün amaç ve sonuç-yöntem ilişkisi noktasındaki stratejilerine bir yol haritası oluşturmak suretiyle dış politikayı etkilerler. Bu noktadan yola çıkarak, bu fikir ve inanışların içerisinde şekillendiği çevrenin temel çerçevesi olarak değerlendirilebilecek bir yapı olan kültür gerek bireysel gerek toplumsal ve kurumsal düzeyde önemli bir etmen olarak ele alınmalıdır.

Vertzberger (1990: 260-261), kültür aracılığıyla içselleştirilen toplumsal (societal) özelliklerin birçok farklı seviyede, doğrudan ve dolaylı biçimde politikayı etkilediğini vurgularken, aradaki nedensel ilişkinin kanıtlanmasındaki zorluğun bu bağlantının olmadığının bir kanıtı olarak değerlendirilmesine şiddetle karşı çıkar. Bu perspektifte ele alındığında, kültürel faktörlerin dış politika noktasındaki etkisinin reddi, argumentum ad ignorantiam* olarak nitelendirilebilir. Carl Sagan'ın (1997: 213) ünlü cümlesi bu yaklaşıma karşı en güzel cevabı

\footnotetext{
"Bilgi eksikliğinden kaynaklanan argüman" (argument from ignorence) olarak Türkçeye çevrilmesi mümkün olan bu Latince ifadenin vurgu yaptığı nokta; herhangi bir olgunun varlığına dair kanıt bulunamamasının, kaçınılmaz olarak o olgunun yokluğuna delil olamayacağı ve o konudaki araştırmanın yetersizliği gibi üçüncü bir ihtimalin de var olduğudur. Kısacası, bir şeyin varlığına ilişkin oluşturulan bu "sahte ikiliğe" (false dichatomy) karşı çıkan bir felsefeyi işaret eder.
} 
verecektir: Kanıtın yokluğu, yokluğun kanıtı değildir. Bu konudaki çalışmaların, söz konusu döneme kadar oldukça sınırlı olarak gerçekleştirilmiş olması, kimileri tarafından kültürel faktörlerin etkisinin olmadığı ya da ihmal edilebilir olduğu sonucuna varılmasına yol açmıştır. Ancak modern çalışmalarda görüldüğü üzere, birçok farklı seviyede bu faktörler dış politika tercih ve kararlarına şekil verme konusunda oldukça etkilidir. Kültürel faktörlerin bu alandaki etkinliğinin inkârı, aynı zamanda, dış politika yapım sürecinin içerisindeki insan faktörünün inkârı anlamında olup, analizi tamamen bir soyutlama içerisine hapseder ve aslında içerisinde yer alması gereken bağlamdan kopma tehlikesiyle karşı karşıya bırakır. Bu anlamda, kültürel faktörlere yapılan vurgu, aynı zamanda çalışmanın elle tutulur temeller üzerine oturması açısından da önemlidir.

Tarih içerisindeki sosyal süreç ve söylemlerle, bulunduğu konuma bağlı olmaksızın toplumun her üyesinin zihnindeki çağrışımları ve genel olarak etkilerini oluşturan ve sınırlayan kültürün, bu anlamda, dış politika ve karar alma sürecinde de çoğu zaman soyut olmakla beraber etkisi oldukça güçlüdür. Kültürel faktörlerin karar alıcılar ve karar alma sürecindeki bürokratik yapılar üzerindeki görece daha somut hal alan etkisini incelemeye geçmeden önce bir devletin dış politika davranışının önemli belirleyicilerinden -belki de en önemlisi- olan ulusal çıkarların yorumlaması noktasında kimlik kavramının etkisi ve ilgili kültürün bu kimliği nasıl biçimlendirdiği üzerinde de durulmalıdır. Kültürü, güç ilişkilerini şekillendirme kabiliyetine sahip dinamik bir güç olarak ele almak ve bir politika aracı olarak değerlendirmek bu noktada faydalı olacaktır.

Dış politika analizinde kültürel faktörlerin etkisi incelenirken çalışmanın sonuç odaklı olmaktan çıkarılması oldukça belirleyici önemdedir. Sadece dış politika çıktısının ele alınması yerine, kültürel etmenlerin yapım sürecindeki konumuna odaklanan bir analiz bize, bir "kara kutu" gibi ele alınan, erişilmesi görece güç olan alanı aydınlatmak noktasında da önemli fayda sunar (Sampson, 1987; Kegley, 1987). Kültürün bu anlamdaki etkisinin görülebilir olduğu noktaların başında, bir aktörün kendisine ve sistemde muhatap olduğu diğer aktörlere atfettiği kimlikler doğrultusunda olası eylemlerini biçimlendirmesi gelir. $\mathrm{Bu}$, bir devletin diğer devletlerle olan ilişkilerinin doğasını etkilerken; aynı zamanda farklı bağlamlarda gerçekleşen benzer olaylara tepkisinin farklılaşabilmesi sonucunu da doğurur. Öznelerarası anlayışın öneminin açıkça ortaya çıktığı bu duruma dair, alandaki neredeyse bütün 
çalışmalarda yer alan klasik bir örnek açıklayıcı olabilir. Amerika Birleşik Devletleri'nin, farklı ülkelerin nükleer kapasiteleri karşısındaki değişen tutumu bu duruma ışık tutmaktadır. ABD, Büyük Britanya'ya göre çok daha sınırlı sayıda nükleer silah sahibi olan Kuzey Kore'ye karşı tavizsiz bir duruş sergilerken, tarihsel müttefikinin bu anlamdaki cephanesi Washington için herhangi bir sorun teşkil etmemektedir. Sosyal süreçler sonucu, toplumların kültürel çerçeveleri içerisinde oluşan karşılık "dostluk/düşmanlık" algılarının belirleyici etkisi bu örnekte açıkça görülmektedir. Bu algılar, karşı karşıya geldiklerinde söz konusu iki aktörün olası davranışları ve eğilimleri noktasında bize ipucu sağlayacaklardır (Wendt, 1995: 73-74). Devletlerarası ilişkiler noktasında aktörlerin beklentileri de bu karşılıklı anlayışlar üzerinden şekillenecek ve dolayısıyla dış politikadaki amaç ve yöntemler üzerinde de etki sahibi olacaktır.

Çıkarlar, hangi perspektiften bakılırsa bakılsın dış politika davranışlarının, amaçlarının ve bu amaçlar doğrultusunda kullanılacak yöntem ve araçların en önemli belirleyicisidir. Bir devletin ulusal olarak nitelenen çıkarları, aidiyet geliştirdiği kimliklerden bağımsız olarak tanımlandığında, sosyal yapılar arasındaki etkileşimin inmal edilmesi suretiyle analizin çok önemli bir noktası eksik kalacaktır. Doğal olarak verili, "bilardo topları" gibi değişimden muaf kabul edilmek yerine, dinamik ve etkileşim sonucu dönüşüme açık bir yapı olarak ele alındığında kimlik, aktörlerin farklı bağlamlarda değiş̧ik biçimlerde yorumlanan çıkarlarının ve çeşitlenen davranışlarının açıklanmasını ya da önceden tahmin edilmesini oldukça kolay hale getirmektedir. Ancak, "(...) siyasi birimin belirli bir uluslararası bağlam içerisinde kendini konumlandırışı" (Banchoof, 1999: 268) ile ilişkili olarak tanımlanan devlet kimliğinin bu yapısı, devlet davranışının öngörülebilmesi adına oldukça önemlidir. Bu noktada, söz konusu davranışın yöneldiği uluslararası olgu ya da olayın içerisinde cereyan ettiği konjonktürün de isabetli bir biçimde analiz edilmesi gerekliliğinin altı çizilmelidir. Bunun yanı sıra, önde gelen inşacı teorisyen Wendt (1992) tarafından altı çizilen "sosyal" ve "kurumsal" kimlik ayrımı da burada vurgulanması gereken bir diğer noktadır. Sosyal kimlik, uluslararası topluluğun söz konusu aktöre ait gördüğü statüye, kişiliğe işaret ederken; kurumsal kimlik bu aktöre sahip olduğu şekli sağlayan, materyal, beşerî, kültürel iç faktörlerin altını çizmektedir. Bu noktada değişen perspektifler, bu yapılardan birini diğerinden önemli kabul etmeye yönelebilmektedir. Sistemik bir bakış açısı ilkini, aktör merkezli bir bakış açısı ise ikincisi 
ön plana çıkarsa da (Reuss-Smit, 2013: 298-299) bu iki yapının, derecesi ne olursa olsun, devletin dış politikası üzerindeki etkisi oldukça fazladır.

Aktörlerin, çıkarlarını nasıl şekillendirdiğini anlayabilmek, uluslararası olguları açıklayabilmek adına temel önemde olan kimlik ile ilgili olarak altı çizilmesi gereken bir başka konu, birçok açıdan dış politika tercih ve davranışlarının üzerinde biçimlendirici etkisi olan "ulusal kimlik" (devlet kimliği) kavramıdır. Toplumun içselleştirdiği kültürel değerler, inanış sistemleri ve çoğu zaman mit haline gelen tarihsel anlatılar bu kimliğin inşasında önemli rol oynar. Hudson'a (2014: 120) göre "kültüre referans vermeden ulusal kimlikten bahsedemeyiz çünkü o [ulusal kimlik] süregelen, dinamik sosyal söylem süreçlerinden meydana gelir." Bu bağlamda, ulusal (resmi) tarih anlatımı ulusal kimlik inşası açısından hayati önemdedir. Ulusal kimlik oluşumu, bir hikâyenin nesiller aracılığıyla aktarımı biçiminde şekillenir. Devralınan bir miras olarak, tarih içerisinde yolculuğuna devam eden bu hikâyenin bir ürünüdür. İçinde bulunulan zamanın şartlarına bağlı olarak farklı yorumlanması mümkün olmakla beraber, temelde, içerisinde bulunulan anın vurgulanan değerlerine bu hikâyeden tarihsel örnekler üretmek suretiyle altyapısı oluşur. Yaratılan ortak bir "biz" duygusu ve bunun "öteki" üzerinden tanımlanması söz konusu hikâyenin ana eksenini şekillendirir (Banerjee, 1997: 31-36). $\mathrm{Bu}$ anlatım, bireylerin belleklerinde mensubu oldukları ulusa dair algıların yerleşmesini sağlar ve bu şekilde söz konusu bireylerin o ulusun devletlerarası ilişkilerdeki rolü ve dış politikadaki tercihleri konusunda beklentilerinin şekillenmesini sağlar. Daha net bir ifadeyle, ulusal tarih anlatımı ve kültür aracılığıyla oluşan ulusal kimlik, aynı dış politika kararlarının farklı toplumlarda farklı biçimlerde yankılanmasına yol açar. Bu yapılar, bir devletin dış politikası üzerinde; hem toplum bazında meşru bir zeminin hazırlanması noktasında hem de karar vericinin dünya görüşünü sınırlayan bir pencere olarak etkili olur. Aynı zamanda, konumu ne olursa olsun, toplumun üyelerinin (karar alıcı noktasındakiler de dahil olmak üzere) uluslararası ilişkilerde söz konusu devletin oynaması beklenen rolün şekillenmesi açısından da tarih ve kültür belirleyici derecede öneme sahip faktörlerin başında gelir (Breuning, 2007: 127, 132).

Dış politika konusunda karar alıcıların en önemli kaygılarının başında kendi toplumunun nezdinde bu kararın -ki bu karar, bir eylemde bulunma ya da bulunmama yönünde olabilir- göreceği 
desteğin boyutudur. Bir dış politika tercihinin meşru bir zeminde kabul edilmesi ve desteklenmesi, iç politikaya yönelik kaygılarla yakından ilgili olmasının dışında, hem devletin bu noktadaki kararlılığını güçlendirmesi hem de gelecek benzer olaylarda da tutarlı pozisyon alabilmesini sağlaması için kritik önemdedir ve bu da ancak toplumsal algıya, yani toplum nezdinde yaygın biçimde içselleştirilmiş olan ulusal kimlik algısına uygun tercihlerin geliştirilmesine sebep olur. Bu bağlamda, sosyalleşme süreçleri ile koşullandırılmış olarak oluşturulan bu algılar bazen sınırlandırıcı yönde bazen de eğilimi belirleyen yönde etkide bulunmaktadırlar. Bu noktada Breuning'in (2007: 129-131) birbirine her anlamda yakın olarak değerlendirilen Belçika ve Hollanda arasında yaptığı karşılaştırma oldukça açıklayıcıdır. Coğrafi, politik ve toplumsal bazda oldukça benzer olan ve uluslararası ticaretin ekonomilerinde önemli yer kapladığı bu iki devletin dış politikasındaki farklı, neredeyse karşıt eğilimler oldukça dikkat çekicidir. Bu farklılaşan eğilimleri, iki devletin taban tabana zıt kuruluş hikayesi anlatılarına dayandıran yazar, Hollanda'nın uluslararası seviyede kayda değer, görece pro-aktif bir politika arayışında olmasını kahramanlık hikayeleriyle bezeli uluslar kuruluş mitlerine bağlarken, Belçika'nın daha "sahne arkası" diplomasisine eğilimli olup, daha ikincil bir role yönelmesini ise doğrudan, ülkenin kuruluşu esnasında etrafındaki daha güçlü devletlere bağımlı olması ise açıklamaktadır. Bir başka deyişle, aradan geçen zaman ne kadar uzun olursa olsun, aktörlerin algılarının inşa edilmesi sırasındaki tarih boyunca anlatılagelen koşulların etkilerini değiştirmek hiç de kolay değildir. Bu noktada altı çizilmesi gereken bir nokta da K. J. Holsti (1970) tarafından ortaya atılan ve dış politika analizindeki önemli faktörlerden birisi olan "ulusal rol" kavramıdır. Bu çalışmanın kapsamı gereği detaylı biçimde incelenmeyecek olan, uluslararası seviyede, belirli bir bağlamda, bir aktörün kendisine atfettiği rolün dış politika davranışının şekillenmesi noktasındaki önemine vurgu yapan bu bakış açısından yola çıkarak ele alındığında, bahsedilen "rolün" kimlikle oldukça yakın ilişkili olduğu ve doğru kabul edilen (axiomatic) toplumsal inanışlar tarafından şekillendirmesi sebebiyle söz konusu toplumun kültürünün etkisiyle oluştuğu gözden kaçırılmamalıdır (Breuning, 1997: 102-103). "Roller (...) içsel ve dışsal olarak ortaya çıkmış, kültürün etkisiyle şekillenmiş beklentilerin ürünleridir" (Chafetz vd., 1997: 170). Dış politika tercihlerinin şekillenmesi açısında bu yapıların etkilerini göz ardı ederek gerçekleştirilen analizin de zayıf olması kaçınılmazdır. 
Buraya kadar, kültürel faktörlerin ve bunların yarattığı kimlik algılarının, devletin dış politika alanındaki genel eğilimini etkileme, yöntem ve araçların seçimleri noktasındaki tercihlerini belirleme bağlamındaki etkileri incelendi. Kültürün bu kapsamda ele alınışında yaşanan değişimle beraber dönüşen dış politika analizi çerçevesinde, bu yapıların özellikle Soğuk Savaş sonrası dönemde artan öznellikle paralel olarak belirginleşen etkinlikleri açıkça görülmektedir. Bu perspektifte hem mikro hem de makro ölçekte kültür ve kimliğe bağlı olarak şekillenen etmenlerin dış politikadaki etkileri karar alma süreçleri incelendiğinde daha da net hale gelmektedir. Karar alıcı birey(ler) seviyesinde olduğu kadar karar alma sürecinin temel bir parçası olan bürokratik yapıların şekillenmesinde kültürel faktörler oldukça önemli bir rol oynamaktadır. Kegley'nin (1987: 247) "karar rejimleri" olarak ifade ettiği, karar alma süreci ve biçimlerinin tercihi noktasında da etkili olan bu faktörlerin incelenmesi, etkinliklerinin tam anlamıyla açığa çıkarılması adına kaçınılmazdır.

\section{KÜLTÜRÜN KARAR ALMA SÜRECİNDEKİ ROLÜ VE ETKİSİ}

Dış politikada karar alma alanındaki çalışmalar açısından çığır açıcı nitelikte olan eserlerinde Snyder, Bruck ve Sapin (2002: 78) karar almayı, "sosyal olarak tanımlanmış, sınırlı sayıdaki ihtimaller ve alternatif projeler içerisinden, karar alıının, ilişkilerin ilerideki belirli bir durumuna dair oluşmasını hedeflediği duruma gelmesi adına yapılan bir seçimle sonuçlanan süreç" olarak tanımlamışlardır. Bu tanımdan yola çıkıldığında, kültürel faktörler, karar alıcı açısından ortaya konan seçenekleri ve bunlar arasında hangisine yönleneceğine dair kişisel eğilimini etkilemenin yanı sıra bir süreç olarak değerlendirilen karar almanın içerisinde şekilleneceği yapı ve bu yapıların organizasyonu anlamında da kritik bir öneme sahip olarak ortaya çıkmaktadır. "Burada dikkat edilmesi gereken nokta, karar alma sürecinin yapısal çerçevesinin devletin örgütleniş biçimi, siyasal rejim ile yakından ilişkisi bulunmakla birlikte özdeş olmadığıdır" (Sönmezoğlu, 2014: 315). Bu durum aslında dışarıdan bakıldığında birbirine benzer yapılar üzerinden organize olmuş devletlerin çok da farklı olmayan konularda farklı dış politika davranışlarını benimsemesinin ardında yatan sebebin kısmen de olsa kültürel farklııılarda aranması gerektiğini işaret etmektedir. Japonya ve Fransa örnekleri üzerinden bu konuya yoğunlaşan Martin Sampson (1987: 403) da bu iki ülkenin kültürel özelliklerinin birbiriyle yer değiştirmesi halinde ortaya çıkacak soncun ve dış politika yapım 
sürecinin radikal bir biçimde farklılaşacağını söylerken bu noktaya vurgu yapmaktadır.

Bundan ayrı olarak, kültürel faktörlerin ve kimliğe dair bilincin karar alma üzerindeki etkisinin belirgin olarak ortaya konduğu nokta, bu sürece dahil olan bireylerin zihinsel ve düşünsel altyapısı üzerindeki şekillendirici etkileridir. Kimi yazarlara göre karar alma sürecinin yapısal doğasının belirlenmesi üzerinden olduğundan çok daha somut olarak nitelenen bu etki (Efegil, 2016: 197) oldukça belirleyicidir. Liderin algısının ve değerlendirme kapasitesinin yanında, hedef saptaması, dürtüleri ve öznel bakış açısının şekillenmesi açısından yarattığı şekillendirici etki düşünüldüğünde bu faktörler, sürecin çıktısının oluşmasında doğrudan etkili olmaktadır. Aynı zamanda, analizde insan faktörünün de net bir biçimde hesaba katılmasının bir sonucu olarak gittikçe önem kazanan bu husus, bir soyutlaştırmanın ürünü olan devletin yanında insanın da analize aktör olarak dahil edilmesinin bir sonucu olarak belirleyici bir nitelik kazanmıştır. Dış politika yapım sürecinin şekillenişi ve organizasyonu ile bu sürece dahil olan birey ya da bireylerin, içerisinde yoğurularak yetiştiği sosyal süreçlerin incelenmesi, uluslararası alandaki aktörlerin farklılaşan eğilimlerinin açıklanması adına kritik önemdedir.

Kültürel faktörlerin dış politika yapımına etkide bulundukları başlıca noktalardan birisi hiç kuşku yok ki kararın alınış süreci ve bu sürece dahil olan yapılar ile ilişkilidir. "Kültürel farklılıkların sadece nihai tercihi değil aynı zamanda karar alma sürecini de etkilediğine dair bol miktarda kanıt mevcuttur" (Mintz, 2010: 145). Her ne kadar devletlerin rejimleri, siyasi eğilimleri, liderlik yapıları, hatta bazen coğrafi olarak konumlandıkları bölgeler bize bu konuda fikir verir nitelikte olsa da bu ve benzeri faktörlerin dış politika kararlarının alınış süreç ve biçimiyle özdeş olarak değerlendirilmesi yerinde bir tutum değildir. Tarihsel süreç içerisinde gelişen geleneksel yapılar ve toplumsal değerler genel olarak çok yakın karakterde gibi görülen iki devletin, benzer durumlar karşısında farklı dış politika hamlelerine yönelmelerini açıklamada önemli önemli bir etki kapasitesine sahiptir.

Burada altı çizilen bu etkinin iki farklı boyutundan bahsedebiliriz. Birincisi, kültürel etmenlerin yarattığı etkinin görece daha zayıf olarak değerlendirilebileceği nokta olan karar alma yapıları üzerindeki etkidir. Söz konusu faktörlerin bu yöndeki etkisinin daha somut ve belirgin bir hal aldığı konu ise daha çok sürecin işleyişi bağlamında ortaya çıkar. Bu ayrıma vurgu yapar biçimde Martin Sampson (1987: 384-405) 
dışarıdan bakıldığında yönetim biçimleri, ekonomik yapıları ve ideolojik eğilimleri karşılaştırılabilir olarak görünen ancak çok farklı, hatta bazen zıt, kültürel dinamiklere sahip Fransa ve Japonya üzerinde yaptığı değerlendirmede, kültür farklıığının karar alma süreci ve buna bağlı olarak, dış politika çıktısı üzerinde çok keskin farklılıklara yol açtığını ileri sürmüştür. Bahsedilen iki ülkedeki dış politika haricinde kalan birçok farklı alandaki karar alma süreçlerinin işleyişi ve toplumsal değerlerin konumları üzerinden gerçekleştirdiği çıkarımları uluslararası seviyedeki kararların alınışına dair gerçekleştirdiği analize uygulayan yazar, geleneksel değerler, kültürel bağlar gibi dinamiklere karşı geliştirilen aidiyet duygusunun dış politika kararları ve bu kararların alınışı noktasındaki belirleyici etkisini net biçimde vurgulamıştır.

Bunun yanında, daha önce bahsedilen, Kegley'nin (1987: 247268) ortaya attığı "karar rejimi" kavramı da yine bu süreç şekillendiren kurallar ve kültürel dinamikler arasındaki bağlantının altını çizer. Çeşitli ülkelerin, dış politika kararlarının alınması noktasında önemli konumlara sahip bireylerle yapılan birçok görüşmenin sonucuna dayanan yazar, karar almanın belirlenmiş kurallar tarafından yönetilen bir süreç olduğu cevabının ülkesi fark etmeksizin her birey tarafından verilmesinden yola çıkarak ve açıkça ifade ettiği üzere aynı dönemde gelişen iş birliği çerçevesinde ileri sürülen uluslararası rejim çalışmalarından da esinlenerek, aynı yaklaşımı dış politikada karar alma analizine uygulamaktadır. Üzerinde uzlaşmaya varılmış ve uluslararası arenada devletin eylem seçeneklerini sınırlayan belirli kurallar olarak tanımladığı karar rejimlerini Kegley, kararın esasına ilişkin olanlar (substantive) ve kararın alınış usulüne ilişkin olanlar (procedural) olarak ikiye ayırmaktadır. Bunlardan ilki, devletin genel dış politika amaç ve görüşüne, kendisini uluslararası alanda konumlandırmasına bağlı olarak gelişirken ikincisi, kararı kimin nasıl aldığı sorularına vurgu yapmaktadır. Öncelikli belirtisi diplomatik alandaki tutarlılık olan karar alma rejimlerine dair kurallar, ulus nezdinde paylaşılan inanışlar, normalar, prensipler ve saygı duyulan temel değerlerle şekillenirken, toplumun gelenekleri ve altı çizilen ortak değerlerin tarihsel süreç içerisindeki evrimi de bu kuralların şekillenmesinde oldukça belirleyicidir.

Karar rejimleri kavramının bu çalışma kapsamındaki önemi, özellikle usule ilişkin rejimlerde ele alınan, bir devlette herhangi bir dış politika kararının nasıl alınacağı belirleyen kuralların, toplumun benimsendiği kültürel değerlerden etkilenerek ortaya çıkan yapılar 
olmasına ilişkindir. Yazılı, resmi kuralların yanında, resmi olmayan kurallar üzerinde kültürün bahsedilen etkisi daha da belirginleşmektedir. Karar alıcının davranış seçimi ve algılarında önemli rolü olan bu gayrı resmî kurallar dikkate alınmadan söz konusu yapıyı tam anlamıyla anlamak mümkün olmayacaktır (Breuning, 1997: 103104). Toplumun ortak değerlerinin, inanışlarının ve algılarının bir sonucu olarak ortaya çıkan bu kurallar, söz konusu kararın toplum nezdinde bir meşruiyet zeminine oturmasını da kolaylaştırırken, aynı zamanda kültürel etmenlerin, karar alma yapıları üzerindeki etkisinin de somutlaşmış hali olarak öne çıkarlar. Hem sosyolojik hem politik anlamda toplumsal kültürün ürünü olan bu yapılar, kararın ilgili olduğu bağlama ya da dış politika alanına göre değişkenlik ya da esneklik gösterebilmekle beraber, kültürle bağlarını değiş̧en ölçülerde de olsa korurlar. Aksi halde, kararın vatandaşların zihninde uygun karşılığı bulamaması ve söz konusu kararla ortaya çıkan eylemin (ya da bir eylemde bulunmama halinin) toplum tarafından benimsenmemesi hem iç hem dış politikada karar alıcı birey ya da grubun konumunun sarsılmasına yol açar.

Kültürün karar alma sürecinde rol alan yapılara olan etkisinin gözlemlenmesi ise ancak bürokratik kurumların şeklinin ve karar alma yönteminin organizasyonel eğilimlerinin incelenmesiyle mümkündür. Dışişleri bakanlıkları, istihbarat örgütleri, askeri kanat gibi bu sürece dahil olan kurumların örgütlenme ve işleyiş biçimleri toplumsal ve siyasi kültürün tam anlamıyla bir yansıması olup alınan kararın doğasını ve alınış şeklini doğrudan etkilerler. Kültürel faktörlerin bu noktadaki etkinliği süreç üzerindeki etki ile karşılaştırıldığında daha sınırlı olsa da bu yapıların da söz konusu etkiden bağımsız şekillenmedikleri göz ardı edilmemelidir. Bu noktada, John Zurovchak'ın (1997: 125-166), yıllarca aynı devletin parçaları olarak yaşamış ve devlet kurumlarının organizasyonu konusunda oldukça benzer tecrübeye sahip Çekya (o dönem Çek Cumhuriyeti) ve Slovakya dışişleri bakanlıkları üzerinde gerçekleştirdiği analizde, ortak tarihi geçmişe rağmen Çek ve Slovak kültürleri arasındaki inkâr edilemez farklılıkların bu kurumların düzenlenmesi, işleyişi ve hiyerarşik otoritenin konumu noktalarında oldukça önemli farklara yol açtığı sonucuna varmıştır.

Bütün bunlara ek olarak, kültürel faktörlerin etkisinin farklı boyutlarda da olsa göz ardı edilemez nitelikte olmasının belki de en temel sebebi, toplumsal hayatın her alanında olduğu gibi, dış politika kararlarının alınmasında da sadece sürecin şekli, bu sürece dahil olan 
yapıların örgütlenmesi ya da aktör gibi temel noktalarla sınırlı olmayıp, mikro ölçekte her olgunun hücrelerine kadar nüfuz etmiş durumda olmasıdır. Kimi zaman yazılı kurallarla kimi zaman da teamül olarak adlandırdığımız, hatta bazen kökenini tam olarak farkında olmadığımız birçok uygulamanın günlük yaşamımızı şekillendirir biçimde etkili olduğu gerçeği, dış politika yapımına ilişkin olarak da geçerlidir. Öyle ki kararın alındığı masanın şeklinden bu masanın etrafındaki oturma düzeninin kurum, mevki ya da bireylere bağlı olarak ortaya çıkmasına, bu süreçte liderin karakterinden bağımsız olarak kendisine atfedilen ya da kendisinin takınması gerektiğine inandığı tutuma kadar birçok noktada bu etki hissedilmektedir. Bu anlamda düşünüldüğünde, kültürel faktörlerin dış politika yapımına farklı seviyelerdeki etkisinin boyutları konusunda kişiden kişiye değişim gösteren fikirler mevcut olsa da sürecin geneline olan etkisinin ihmali analizde önemli derecede bir eksiklik yaratacak değişkenin göz ardı edilmesi anlamına gelir.

Kültür, karar alma yapılarının, sürecinin ve yönteminin içerisinde şekillendiği çevrenin temel belirleyeni ve çerçevesini oluşturan faktör olarak dış politika yapımının en temel etmenlerinden bir tanesidir. Bu noktadaki konumunun önemi, bütün bunlara ek olarak, sürecin yapısından bağımsız biçimde en temel aktör rolünü üstlenen bireyin fikir ve davranış yönelimlerinin altyapısını oluşturması nedeniyle daha da artmaktadır. Bireylerin kişiliklerinden kaynaklanan farklılıkları yok saymamakla birlikte içerisinde yetiştikleri kültürün, hayatlarının her alanında olduğu gibi uluslararası politika alanındaki eğilimleri üzerinde de merkezi bir konumda olduğunun vurgulanması bu bağlamda oldukça kritiktir.

Bu bağlamdaki çalışmaların temel çıkış noktasını, her biri belirli sosyal yapıların bir parçası olan karar alıcı bireylerin toplumsal sistemden ve etkilerden izole biçimde hareket eden aktörler olarak kabul edilmemesi gerekliliği oluşturur. Unutulmamalıdır ki karar alma mekanizmasına katılanlar da dahil olmak üzere bireylerin zihin yapıları dış etkiye kapalı, bulundukları mevkiye ulaşana kadar çevre etkisine maruz kalmamış boş defter yaprakları değildir. Her biri, zaman içerisinde, aileden başlayarak birçok toplumsal yapı ile etkileşime girerek şekillenmiş ve çeşitli sosyal süreçler aracılığıyla inşa edilmişlerdir. Söz konusu bireylerin "(...) bir boşlukta görevlerini ifa edermişçesine" (Snyder vd., 2002: 40-41, 76) ele alınamayacak olmasının yanı sıra "(...) zihinlerinin de bir 'tabula rasa' olarak değerlendirilmemesi" (Hudson, 2005: 10) yönündeki olmazsa olmaz 
şart, sosyal ve kültürel faktörlerin karar alıcı üzerindeki çok boyutlu etkilerinin temel dayanaklarını oluşturur. Kısacası, içerisinden çıktıların toplumun temsilcileri oldukları kadar birer ürünü de olan bireylerin değerleri, algıları, dürtüleri, kendilerine, temsil ettikleri devlete ve muhatap oldukları sorun ve aktöre yönelik algıları ve bütün bu faktörlerin şekillenmesini sağlayan sosyal ve toplumsal süreçler, alınan karar, kararın alınış süreci ve tercih edilen yöntem açısından temel belirleyici etmenleri oluştururlar.

Bu çerçevede, ilk olarak altı çizilmesi gereken nokta, karar almaya ilişkin olarak seçeneklerin belirlenmesi, bu belirlenenlerden birinin seçilmesi ve buna ilişkin olarak söz konusu uluslararası olay ya da olgunun tanımlanmasıdır. Karar alıcı noktasındaki birey(ler)in bu olay ya da olgunun çerçevelenmesi (framing) noktasındaki yönelimi, ilk etapta tamamen zihinsel bir süreç olup kendilerini bağlı hissettikleri fikir ve değerlerden olduğu kadar önyargı ve temsil ettikleri devletin orta ve uzun vadedeki ilerleyişi hakkındaki şahsi bakış açılarıyla doğrudan ilintilidir. Farklı biçimde ifade edilirse, kültürel faktörlerin etkisi, daha karar alma sürecinin ilk aşamalarından olan, içinde bulunulan bağlamın tanımlanması ve seçeneklerin belirlenmesi konusunda etkili olarak ortaya çıkar. Bu noktada analize dahil edilen psikolojik yaklaşım ile ele alındığında, bireylerin "bilişsel tutarlılık" kavramının doğal bir sonucu olarak önceki bilgi, inanış, çağrışım ve yargılarıyla paralellik ya da uygunluk teşkil etmeyen bilgileri önemsememesi olayın çerçevelenmesi ve buna bağlı olarak seçeneklerin sıralanması açısından bireye bağlı olarak gelişen farklar yaratmaktadır ve bu farklar, her analiz seviyesinde görünür hale gelir (Mintz ve DeRouen Jr., 2010: 98, 101).

Bu perspektifte, kültürel faktörler, toplumun her bireyine olduğu gibi karar alıcıya da belirli bağlamlarda başvurulmak üzere bir eylem repertuarı sunar. Aynı zamanda, içinde bulunulan çevreyi ya da karşılaşılan durumu anlama, yorumlama noktalarında ve gelen bilginin alınıp işlenmesine ilişkin, bireyin kullanmak için hazır beklettiği "gözlükleri" de kültürel faktörlerin yaşamı boyunca şekillendirdiği inanış ve değerler aracılığıyla oluşmuştur. Sahip olunan inanışlar, geçmiş tecrübeler, kişinin kendisini bağlı hissettiği değer ve ilkeler gibi birçok değişken sürece bu noktada dahil olurken bütün bunların belirlenmesinde temel rol, karar alıcının içerisinde yetiştiği toplumun kültürüne atfedilebilir niteliktedir. Kısacası, karar alıcı birey, diğer her insan gibi, aldığı bilgiyi yorumlayıp karşı karşıya kaldığı sorun ya da 
olguyu tanımlarken, çoğu zaman farkında olmadan, bu faktörlerin etkisi altında hareket eder. Bu anlamda, karar alıcıların insanüstü varlıklarmışçasına tamamen rasyonel ve objektif süreçler sonucunda bir karara vardıklarını varsaymak, gerçekçilikten uzak bir yaklaşım olmasının yanında, kapsamlı bir analizi de engelleyecektir.

İçinde bulunduğumuz alan dış politika gibi hayati öneme sahip başlıca alanlardan biri olduğu için bu alanda karar alıcı noktaya ulaşmış ya da karar alama sürecini etkileyebilecek pozisyona erişmiş olan bireyin bir şahsi vizyonunun olması ve bu vizyonun bu süreçte baştan sona önemli bir etkinliğe sahip olması hiç de beklenmedik bir durum değildir. Unutulmamalıdır ki söz konusu vizyonun kökenleri de yine toplumun kültürel normlarında ve yargılarında bulunur. Hatta bir adım daha ileri giderek, bireyin yetiştirilme tarzı ve eğitimi aracılığıyla dahil olduğu bu toplumsal yapının, ne kadar farkında olduğu fark etmeksizin, belirli ölçüde karar alıcının tarih ve uluslararası ilişkiler noktasındaki kavrayışının sosyal ve kültürel olarak koşullandırımış olmasına yol açtığını da söylemek mümkündür. Merkezinde alışılmış olanın doğal kabul edilmesi durumu bulunan ve sosyolojik bağlamda, "içerisinde bulunulan kültürün davranış biçimlerinin benimsenmesi" anlamını taşıyan "enculturation" kavramı tam da bu noktada öne çıkmaktadır. Söz konusu kültürel değerlerin, normların ve davranış biçimlerinin yorumlanması bireyler arasında farklılık gösterse de bu faktörler, "yol gösteren kısıtlamalar" olarak bireyin davranış tercihine etki eder (Breuning, 2007: 127-129). Bu bağlamda, aynı kültürde yetişmiş her bireyin aynı karara varacağı sonucu çıkarmak imkânsız olsa da kültürel faktörler tarafından belirlenmiş belirli sınırlar içerisinde kalmasının kaçınılmaz olduğu açıktır. Bir başka deyişle, kültür bize aktörün kısa vadedeki davranışının ne olacağını öngörme konusunda çok yardımcı olmayabilir; ancak, dış politika bağlamında neyin mümkün olmadığını, karar alma sürecinde ilk elenen seçeneklerin neler olacağını tahmin etme noktasında oldukça faydalıdır (Hudson, 2014: 136).

Liderlerin kişilikleri tarafından içselleştirilmiş, toplumun kültürel kalıplarından kaynaklanan inanışları ve bunların dış politika kararları üzerindeki etkisinin incelenmesi adına başvurulan yaklaşımlardan birisi de Nathan Leites tarafinda yayınlanan The Operational Code of the Politburo (1951) A Study of Bolshevism (1953) başlıklı eserlerde öne sürülen "operasyonel kod" (operational code) analizidir. Liderin sahip olduğu temel inanışların dış politikaya ilişkin tercih ettiği karar ve yöntemlere etkisini ortaya koymayı amaçlayan bu yaklaşım, bir 
anlamda, kültürel faktörler çerçevesinde ele alınan bu inanışların aktörün uluslararası düzeydeki davranışıyla bağlantısını kurmaktadır (Hudson, 2014: 132; Mintz ve DeRouen Jr., 2010: 102-103). Daha çok dış politika analizindeki bilişsel boyuta odaklı çalışmalarda kullanılan bu analizin bizim çalışmamız açısından önem arz eden kısmı, kültürel faktörlerin, buraya kadar bahsedilenler dışında, liderlerin kişilikleri aracılığıyla da karar alma süreçlerini etkilediğini ortaya koymasıdır. Liderler tarafından sosyal süreçler aracılığıyla içselleştirilerek kişiliklerinin bir parçası haline gelen kültürel norm ve değerlerin, bireylerin zihinsel ve düşünsel yapılarını şekillendirip, çeşitli bağlamlarda uygulanan davranış ve karar alma yöntemi tercihlerine etki etmesini göstermesi açısından bu analizin katkısı oldukça kayda değerdir.

Toplum içerisindeki kültürel dinamiklerin bir ürünü olan bireyin aidiyet bağı ile bağı olduğu kimlikler de dış politika kararı açısından belirleyicidir. Öncelikle belirtilmelidir ki bir birey, içerisinde bulunduğu şartlar, karşısındaki muhatabını algılayışı ve karşı karşıya olduğu uluslararası olay ya da olguyu yorumlayıp tanımlaması gibi birçok değişkene bağlı biçimde farklııı gösteren çeşitli kimliklere bağlılık duyabilir. Toplumun ulusal kimliğini bu anlamda benimsemiş karar alıcılar, kararlarının toplumsal bazdaki meşruiyetini sağlama noktasında görece avantajlı olsalar da milyonlarca bireyden oluşan ve yaratmış oldukları homojenlik algısı gittikçe zayıflamakta olan günümüz uluslarında bunu tam anlamıyla başarmak pek de olası değildir. Dolayısıyla, kültürel faktörlerin etkisiyle şekillenen ve karar alıcı birey ya da elitin dünyaya bakışını ve algısını biçimlendiren kimliksel bağlar, bu haliyle dış politika yönelimlerinin de ortaya çıkışında belirgin bir rol oynar.

Bu noktada, ihmal edilmemesi şart olan önemli bir ayrıma dikkat çekmek gereklidir. Bireysel kimlik denildiğinde her ne kadar ilk akla gelen etnik, ulusal, dini, ekonomik kimlik ve bunlara benzer, görece dinamik olmayan kavramlar akla gelse de kastedilen sadece bu kimlik yapıları değildir. Bütün bunlara ek olarak, bireylerin sahip oldukları konumlara bağlı olarak gelişen ve haliyle, bu konumlarda meydana gelen değişikliklerden doğrudan etkilenen bireysel kimlikler de aynı derecede önemlidir. Bir başka ifadeyle, bir uluslararası sorunun yorumlanması noktasında ilgili ülkenin vatandaşı olan birinin başbakan iken benimsediği yaklaşımla, askerken belirlediği farklı, yerel siyasetle meşgulken ya da ulusal güvenlikle ilgisi olmayan bir işle uğraşırken 
takındığı tutum farklı olacaktır. Yine aynı şekilde, asker kökenli bir lider ile bürokratik yapılardan gelme bir diğer liderin aynı sorun karşısında çok farklı hatta bazen taban tabana zıt yaklaşımlara yönelmesi de oldukça olağan bir durumdur.

İki grup halinde ele alınan bu bireysel kimliklerin her ikisinin de dış politika noktasında belirli bağlamlarda etkili olması söz konusudur. İlk gruptakilerin etkisine baktığımızda temel belirleyicinin toplumun homojenlik seviyesi olduğu söylenebilir. Yani, "toplumun sosyal farklılaşma düzeyi düşünüldüğünde, zenginliğin toplum geneline dağılımı, fakir ile zengin arasındaki ayrımın azalması, bölgecilik düzeyi, toplumun birliktelik derecesi ile toplumun bir kısmının, kendisini toplumun bir parçası olarak görmesi veya görmemesi gibi unsurlar da dış politikayı etkilemektedir" (Efegil, 2016: 198). Aynı şekilde, karar alma sürecine nüfuz etme kapasitesine sahip noktalarda yer alan bireylere ilişkin benzeri durumlar da bu noktada etkili olmaktadır. Örneğin, yakın dönem Türkiye tarihinin en kritik dış politika kararlarından birisi olan, ABD'nin Irak'a yönelik müdahalesine asker gönderilmesine ilişkin tezkerenin Türkiye Büyük Millet Meclisi tarafından reddedilmesinde dönemin Güneydoğulu ve Kürt kökenli milletvekillerinin ret oyu kullanması belirleyici olmuştur (Ibid.). İkinci gruptaki dinamik bireysel kimlikler olarak niteleyebileceğimiz kimliklerin dış politika kararları üzerindeki etkisine gelince ise durum daha kolay anlaşılabilir bir hal almaktadır. Genel anlamda uluslararası düzeydeki eğilimleriyle uzlaşmacı kimliği öne çıkan diplomatik kadrolarda yetişmiş bir liderin ülkesine yönelen yaşamsal bir tehdit karşısında yine bu kimliğin gerektirdiği biçimde davranacağını ileri sürmek pek de gerçekçi olmayacaktır. Farklı bir açıdan bakarsak, grup dinamikleri ile karar alma biçiminde organize olmuş bir süreçte aynı konu karşısında, askeriyeyi temsil eden bireylerin ilk etapta askeri yöntemlerle konunun ele alınmasını savunurken, Dışişleri Bakanlığı gibi sivil bir grubun üyesi olarak orada bulunan kişilerin son ana kadar askeri çözümden kaçınıp diplomatik yollarla soruna çözüm aranması konusunda fikir beyan etmeleri oldukça olağandır. Özümsenmiş olan bireysel kimliklerin dış politika çıktısı üzerindeki etkisi de tam da bu biçimde ortaya çıkmaktadır. Farklılıkların yönü ve boyutu değişken olmakla birlikte değişik çevrelerde birbirinden uzak sosyal süreçlerden geçerek bir noktaya ulaşmış bireylerin hepsinin bir konuya ilişkin algı ve eğilimlerin aynı olması imkânsız değilse de oldukça düşük bir intimale işaret eder. Bu ve benzeri farklılıklar, istisnai örneklerin varlığı 
kabul edilmekle beraber, tamamen söz konusu bireylerin bulundukları konuma bağlı olarak geliştirdikleri kimlik aidiyetlerinin doğal bir sonucu olup, uluslararası düzeydeki kararları doğrudan etkilemektedir.

Özetle, dış politikada karar alma analizi çerçevesinde temel aktörün, dış politikayı yapan ve uygulayan olan birey olarak kabul edilmesi kültürel ve kimlikle ilişkili faktörlerin analize dahil edilmesini kaçınıımaz kılmaktadır. Konumu fark etmeksizin, bireylerin dünyayı ve uluslararası arenayı algılayışı, yorumlayışı ve bunun karşısında geliştirdiği davranış ve yöntem tercihleri, doğrudan veya dolaylı olarak bahsedilen faktörlerin etkisiyle şekillenmektedir. Kültür, bireyin dışarıya baktığı pencere, kimlik ise bu pencereden bakarken görmesini sağlayan bir gözlük olarak nitelenebilir. Aktörün görüşünün sınırları kültürel faktörler aracılığıyla şekillenirken, gördüklerine dair algıladığı detaylar, söz konusu bağlamla ilişkili biçimde aidiyet geliştirdiği bireysel kimliğiyle bağlantılı olarak ortaya çıkmaktadır.

\section{SONUÇ}

Kültürel faktörlerin ve kimlik aidiyetlerinin dış politikada karar alma kapsamındaki yerinin göz ardı edilemez nitelikte olduğu vurgusu taşıyan bu çalışmada ele alındığı üzere bu faktörler, birçok farklı düzlemde, aktörlerin uluslararası seviyedeki davranışlarının şekillenmesine etkide bulunmaktadır. Ortak anlamlandırmaların oluşturulması, paylaşılan değerlerin tercihleri ve/veya uygun davranış kalıpları ve seçenekleri olarak ele alındığında kültürel faktörlerin ve bunlara bağlı olarak oluşan ulusal ya da bireysel kimlik aidiyetlerinin karar alma açısından önemi açıkça ortaya çıkmaktadır (Hudson, 1997). Bu çerçevede bakıldığında gerek devletlerin çevrelerini anlamaları ve olanları anlamlandırmaları açısından gerekse karar alma yapı ve sürecinin oluşumu açısından, kültürel faktörler belirleyici etmenler olarak göze çarpmaktadır. Buna ek olarak, karar alma sürecinin temel aktörü olan bireyin düşünsel ve algısal altyapısını şekillendirmek suretiyle de bu faktörler, kaçınılmaz biçimde dış politika kararları üzerinde görünür izler bırakırlar.

Ancak, akıldan çıkarılmamalıdır ki ne bu çalışmada ne de bu perspektifte gerçekleştirilen diğer analizlerin hiçbirinde ileri sürülen fikir, aktörün kültürel özelliklerine ve/veya kimliğine ilişkin faktörlerin dış politika kararı noktasında tek ya da temel belirleyici olduğu değildir. Vurgulanan nokta, kısmen disiplin içerisindeki yükselen eğilimlerin, kısmen de uluslararası siyasete hâkim konjonktürün yarattığı etkinin 
sonucunda, özellikle Soğuk Savaş sürecinde, söz konusu etmenlerin bu çerçevedeki rolünün azımsanır hale gelmesi durumunun son dönemde aksi yönde bir gelişme göstermesi ve bu yönelimin belki de geç kalınmış olumlu bir adım olarak altının çizilmesi gerekliliğidir. Son dönemde, yıllar boyunca alışılagelmiş iç politika-dış politika ayrımı birçok farklı açıdan, siyasi ve kavramsal olarak tartışılır hale gelmiştir (Hill, 2003: 1). Bu durum, ister istemez, dış politika yapımının geleneksel olarak kabul edilmiş faktörlerle sınırlı biçimde ele alınmasını gerçekçilikten uzak kılmaktadır. Bunun yanında, kültürel çevreye yapılan bu vurgu, hiçbir şekilde bireysel farklılıkların daha geniş bir potada eritilerek göz ardı edilmesi olarak görülmemelidir. Bir başka deyişle, burada, kendilerini benzer kimliklerle tanımlayan, aynı kültüre mensup olan her bireyin aynı uluslararası olay ya da olgu karşısında birbirinden farksız davranışlara yöneleceği gibi bir iddia ileri sürülmemektedir. Savunulan fikir, bu durumdaki bireylerin, davranışlarını benzer seçenekler içerisinden seçecek olmalarıdır. Yani, bireyin seçimini ön görmek olanaklı olmasa da kültürel faktörleri merkeze alan bir analiz aracılığıyla, hangi ihtimalin seçenekler dışında kalacağını, bir başka ifadeyle, bireyin neyi yapmayacağını öngörmek mümkün hale gelmektedir. Bu anlamda kültür, dış politikada karar alma analizinde hesaba katılan diğer bütün faktörleri tamamlayıcı ve destekleyici nitelikte önemli bir katkı sunmaktadır.

Uluslararası aktörlerin kültürel manada oldukça heterojen bir kültürel yapı teşkil etmeleri, aralarındaki sayısız etkileşimler bağlamında, bir o kadar kimlik üreterek davranışlarını şekillendirmeleri, bu çerçevedeki analizi ve geniş kitleler tarafından kabul gören büyük genellemelerin ortaya çıkmasını oldukça zor hale getirmektedir (Snyder vd., 2002: 53). Bu anlamda, tek geçerli yöntem olmamakla birlikte, karşılaştırmalı bir bakış açısıyla geliştirilen analizler, kültürel farklııkların etkisini ortaya serme noktasında önemli bir kolaylık sağlamakta ve tek bir aktöre odaklı daha derin çalışmalar adına önemli bir altyapı sunmaktadırlar. Uluslararası ilişkiler disiplinine yaptığı bu katkının yanında, söz konusu faktörlerin, dış politika uygulayıcıları tarafından da kararların alınışı esnasında hesaba katılır hale geldiği taktirde hem devletler arasındaki beklenti ve yönelimlerin uyumlu hale gelmesi hem de uluslararası arenanın, aktörler arasındaki anlaşmazlıklardan uzaklaşılarak düzenlenmesi noktasında umut vadeden bir gelecek sunacağına ve kültürel farklılıklardan kaynaklı 
çatışmaları en azından azaltacağına, hatta yok edeceğine inanmamak için hiçbir sebep bulunmamaktadır.

\section{KAYNAKÇA}

Almond, G. \& Verba, S. (1989). The Civic Culture : Political Attitudes and Democracy in Five Nations. California: SAGE.

Baklacıoğlu, N. Ö. (2014). Uluslararası İlişkiler Disiplininde Dış Politika Analizinin Gelişimi. içinde (Ed.). Özgün Erler Bayır \& Faruk Sönmezoğlu. Dış Politika: Karşılaştırmalı Bir Bakış (45-73). İstanbul: Der.

Banchoff, T. (1999). German Identity and European Integration. European Journal of International Relations 5(3), 259-289.

Banerjee, S. (1997). The Cultural Logic of National Identity Formation: Contending Discourses in Late Colonial India. içinde (Ed.). Valerie M. Hudson. Culture and Foreign Policy (27-44). Boulder: Lynne Rienner.

Barnette, M. (1993). Institutions, Roles, and Disorder: The Case of the Arab States System. International Studies Quarterly 37(3), 271-296.

Breuning, M. (1997). Culture, History, Role: Belgian and Dutch Axioms and Foreign Assistance Policy. içinde (Ed.). Valerie M. Hudson. Culture and Foreign Policy (99-123). Boulder: Lynne Rienner.

Breuning, M. (2007). Foreign Policy Analysis: A Comparative Introduction. New York: Palgrave Macmillan.

Burchill, S. \& Linklater, A. (2013). Giriş. içinde (Ed.). Scott Burchill vd. Uluslararası İlişkiler Teorileri (11-51). İstanbul: Küre.

Chafetz, G., Abramson, H. \& Grillot, S. (1997). Culture and National Role Conceptions: Belarussian and Ukrainian Compliance with the Nuclear Nonproliferation Regime. içinde (Ed.). Valerie M. Hudson. Culture and Foreign Policy (169-200). Boulder: Lynne Reinner.

Efegil, E. (2016). Dış Politika Analizi: Ders Notları. İstanbul: Nobel.

Gaenslen, F. (1997). Advancing Cultural Explanations. içinde (Ed.). Valerie M. Hudson. Culture and Foreing Policy (265-279). Boulder: Lynne Reinner.

Goldstein, J. \& Keohane, R. (1993). Ideas and Foreign Policy: An Analytical Framework. içinde (Ed.). Judith Goldstein \& Robert Keohane. Ideas \& Foreign Policy: Beliefs, Institutions, and Political Change (330). New York: Cornell University. 
Hermann, M. G. \& Kegley, C. W. (1995). Rethinking Democracy and International Peace: Perspectives from Political Psychology. International Studies Quarterly 39(4), 511-533.

Heywood, A. (2011). Global Politics. London: Palgrave Macmillan. Hill, C. (2003). The Changing Politics of Foreign Policy. New York: Palgrave Macmillan.

Holsti, K. J. (1970). National Role Conceptions in The Study of Foreign Policy. International Studies Quarterly 14(3), 233-309.

Hopf, T. (1998). The Promise of Constructivism in International Relations Theory. International Security 23(1), 171-200.

Hudson, V. M. (2005). Foreign Policy Analysis: Actor-Specific Theory and the Ground of International Relations. Foreign Policy Analysis 1(1), 1-30.

Hudson, V. M. (2014). Foreign Policy Analysis: Classic and Contemporary Theory. Maryland: Rowman\&Littlefield.

Hudson, V. M. (Ed.). (1997). Culture and Foreign Policy. Boulder: Lynne Reinner.

Huntington, S. P. (1996). The Clash of Civilizations and the Remaking of World Order. New York: Simon \& Schuster.

Sayfa | 1081

Johnston, A. I. (1995). Thinking About Strategic Culture. International Security 19(4), 32-64.

Kegley Jr., W. C. (1987). Decision Regimes and the Comperative Study of Foreign Policy. içinde (Ed.). Charles F. Hermann, Charles W. Kegley Jr. \& James N. Rosenau. New Directions in the Study of Foreign Policy Analysis (247-268). London: Harper Collins Academic.

Lapid, Y. (1996). Culture's Ship: Returns and Departures in International Relations Theory. içinde (Ed.). Yosef Lapid \& Friedrich Kratochwil. The Return of Culture and Identity in IR Theory (3-20). Boulder: Lynne Rienner.

Leites, N. (1951). The Operational Code of the Politburo. New York: McGraw-Hill.

Leites, N. (1953). A Study of Bolshevism. New York: Free Press.

Liland, F. (1993). Culture and Foreign Policy: An Introduction to Approaches and Theory. IFS Info. No.1.

Mintz, A. \& DeRouen Jr., K. (2010). Understanding Foreign Policy Decision Making. New York: Cambridge University. 
Morin, J. F. (2013). La Politique Étréngère. Paris: Armand Collin. Price, R. \& Reuss-Smit, C. (1998). Dangerous Liaisons? Critical International Relations Theory and Constructivism. European Journal of International Relations 4(3), 259-294.

Proust, M. (2000). In Search of Lost Time, Vol. 6: Time Regained and A Guide to Proust. London: Vintage.

Pye, L. W. (1991). Political Culture Revisited. Political Psychology 12(3), 487-508.

Reuss-Smit, C. (2013). Konstrüktivizm. içinde (Ed.). Scott Burchill vd. Uluslararası İlişkiler Teorileri (285-314). İstanbul: Küre.

Rosenau, J. N. (1980). The Scientific Study of Foreign Policy. Revised and Enlarged Edition. London: Frances Pinter Publishers.

Rosenau, J. N. (1990). Turbulence in World Politics: A Theory of Change and Continuity. Princeton: Princeton University Press.

Sagan, C. (1997). The Demon-Haunted World: Science as a Candle in the Dark. New York: Ballentine.

Sampson, M. W. (1987). Cultural Influences on Foreign Policy. içinde (Ed.). Charles F. Hermann, Charles W. Kegley Jr. \& James N. Rosenau. New Directions in the Study of Foreign Policy (384-405). London: Harper Collins Academic.

Snyder, R. C., Bruck, H. W. \& Sapin, B. M. (2002). Foreign Policy Decision-Making (Revisited) by Valerie M. Hudson, Derek H. Chollet, and James M. Goldgeier. New York: Palgrave Macmillan.

Sönmezoğlu, F. (2014). Uluslararası Politika ve Dış Politika Analizi. İstanbul: Der.

Vertzberger, Y. (1990). The World in their Minds: Information Processing, Cognition, and Perception in Foreign Policy Decisionmaking. California: Stanford University.

Wendt, A. (1992). Anarchy Is What States Make of It: The Social Construction of Power Politics. International Organization 46(2), 391425.

Wendt, A. (1995). Constructing International Politics. International Security 20(1), 71-81.

Zurovchak, J. F. (1997). Cultural Influences on Foreign Policy Decisionmaking: Czech and Slovak Foreign Policy Organizations. içinde 
Dış Politikanın Sosyal İnşası: Kültürel Faktörlerin Karar Alma Yapılarına Artan Etkisi Can Donduran

(Ed.). Hudson Valerie M. Culture and Foreign Policy (125-166). Boulder: Lynne Rienner. 